\title{
Decentralised governance and planning in India: case study of a tribal district
}

\section{Bishnu Prasad Mohapatra}

Centre for Economic and Social Studies, Begumpet, Hyderabad

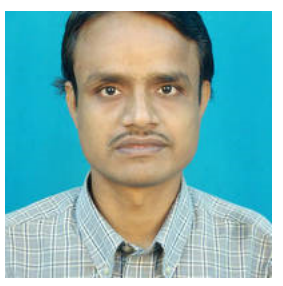

\begin{abstract}
This paper examines the process of the formulation of decentralised planning in the Tribal regions of Odisha, a state located in eastern part of India, while examining the powers devolved to the local governments in such regions in the state to formulate plan, and the ground reality of the preparation of such plans in the context of the implementation of the Provisions of Panchayats (Extension to Scheduled Areas) Act (PESA Act). Formulation of decentralised planning in Odisha was taken up in the year 2008. However, based on the secondary data and interacting with the various people in field, the paper has revealed that "structural impediments" and "functional incapacity" of the local governments in the Scheduled Areas have hampered the spirit of such institutions with regard to the planning and implementation of the development programs. The paper argues that decentralised plans should be realistic, based on the effective utilisation of local resources, and the local development issues should be prioritised and implemented accordingly. The paper suggests policy measures such as effective participation, prioritisation of development needs, and rationalisation of the required and available funds, considering the significance of the PESA Act. While doing so, the issues of the tribals should receive priority.
\end{abstract}

Key Words: Decentralised Planning, scheduled areas, PESA Act, local governments, Odisha, Sundargarh

\section{Introduction}

The increasing global debate on functioning of the local self-governments has attracted many scholars of the world to explore on the various aspects of functioning-particularly with regard to promoting local development plan and implementing development programmes. It is widely believed that in the contemporary era of development the local self-governing institutions have been playing a prominent role while contributing immensely towards formulating local development plan and implementing development programmes for the people while focusing on disadvantageous section of people (Tribals and Women). This argument has become a major source of developing new scholarship on the study 
of local government and planning while focusing on the participation and programme implementation. In the case of India the local self-governing institutions (LSGIs) have been playing a catalytic role in the planning and implementation of development programs. The $73^{\text {rd }}$ Amendment Act of the Indian Constitution has spelt out the role of the LSGIs regarding the preparation of development plans (plans for promoting socio-economic development programmes) while considering the nature and extent of poverty and backwardness of rural areas. As per the provision of this Act, mandatory powers and functions have been vested to the Gram Sabhas (Village Assembly) to promote local development plans and to identify beneficiaries under different schemes and programmes. The provisions of the Panchayats (Extension to Scheduled Areas) Act (PESA Act), 1996, also emphasised the role of the LSGs in the Schedule V areas ${ }^{1}$, in the preparation of development plan and the implementation of development programs.

The PESA Act has given legislative powers to the Gram Sabhas ${ }^{2}$, specifically in matters of planning for development, management of natural resources, and adjudication of decisions in accordance with prevalent traditions and customs (Upadhya, 2007). The provisions of this act also further spelled out the role of the Gram Sabhas in matters pertaining to: (i) the approval of plans for the village Panchayats $^{3}$, (ii) identification of beneficiaries for the schemes under poverty alleviation and other programmes, and (iii) the issuance of certificates for the utilisation of funds by the Panchayats. Further, while formulating the plans for the village Panchatays, the Gram Sabhas must provide adequate emphasis on the community resources available as well as the customary laws, traditions, customs, and cultural identity of the tribal people. However, after 15 years of implementation of the progressive legislation (PESA),there is a growing realisation that while the burden of "implementation" of development programs has been vested, "control" over planning and resources is still in the hands of the bureaucratic elite.

In the case of Odisha (a state located at the eastern part of India), decentralised planning ${ }^{4}$ has taken a new shape since the Eleventh Five-Year Plan Period (2007-12) when there was an emphasis by the Planning Commission on the preparation of a decentralised Development Plan for each district. The process (formulation of District Development Plans) was initiated by the State Government during the year 2008, in which the LSGIs at their respective levels were given a lead role apart from the Line Departments, District Planning Offices, and NGOs. However, in Scheduled Areas, the process did not receive special attention, despite the constitutional mandate for institutionalisation of the Gram Sabhas for planning, as per the provision of the PESA Act.

\footnotetext{
${ }^{1}$ Areas described under the provision of the $5^{\text {th }}$ Schedule (schedule v) of the Indian Constitution.

2 The $73^{\text {rd }}$ amendment of the Indian Constitution defines Gram Sabhas as "a body consisting of persons registered in the electoral rolls relating to a village comprised within the area of Panchayat at the village level".

${ }^{3}$ Panchayat means an institution of self-government constituted under article 243B of Indian Constitution for the rural areas.

${ }^{4}$ Decentralised planning refers to plan formulated by the panchayats at the village level for the implementation of the socio-economic development programmes in the rural areas.
} 
In the case of Sundargarh District of Odisha, the process was taken up in 2008 (2008-2009 financial year) which was considered as a landmark in the history of the district planning initiative. However, it has been observed that the process is more ceremonial rather than creating genuine change in the formulation of the District Development Plan. The planning process has also raised several questions as far as issues of implementation, participation, and resource allocation are concerned. Being a scheduled area district ${ }^{5}$ and despite the implementation of the PESA Act, there has been no emphasis on tribal development issues in the planning process. It is also worth mentioning here that the patterns followed for the planning have aptly ignored institutions such as the Gram Sabha and Gram Panchayats, which in turn invite the emergence of bureaucratic culture in the planning process. The process has also raised a dozen questions regarding the efficacy of the Panchayati Raj Institutions (PRIs) because of their failure in managing such a gigantic task due to inadequate infrastructure facilities, poor data management system, insufficient staff and a huge capacity gap.

By examining all the above trends, the present paper has tried to unpack the process of the formulation of decentralised Development Planning, while highlighting the case of Sundargarh District. The analysis in this paper reflects three broad realms of decentralised planning and the PESA Act. In the first part, there is a conceptual discussion about the LSGs and decentralised planning in Odisha in general and in the context of the Scheduled Areas (Tribal Areas) in particular. In the second part, the case of formulation of decentralised planning of Sundargarh District has been highlighted to understand the process. The last part provides an analytical scenario of the achievement of decentralised planning and draws a set of conclusions (policy recommendations) in order to emphasise the significance of the PESA Act for Development Planning in Scheduled Areas.

\section{Local governments and decentralised planning in India: the case of PESA Act.}

It is argued that decentralised planning always helps to promote equitable development and inclusive growth at the grass-root level by prioritising the people's needs and aspirations. In decentralised planning, the local organisations and institutions formulate, adopt, execute actions and supervise the plan without interference by the central body. In this type of planning, people are considered as an important and inseparable part of the planning process. The local people on the basis of their "time and place knowledge", develop plans and participate in the decision making process of the local governments for the implementation of such plans which ultimately helps towards effective implementation of the development programs. Thus decentralised planning is believed to create opportunities for effective people's participation in the planning process.

\footnotetext{
${ }^{5}$ Indian constitution under Article 274(I) defines the administration and governance of the scheduled areas and the districts comes under this provision usually known as Scheduled Area Districts or Scheduled Districts or Tribal District.
} 
Decentralised planning has a long and cherished history of evolution in India. The concept which flourished gradually since the First Five-Year Plan has evolved through different stages while giving paramount importance to "people's participation" in the planning and implementation of such plans. From the original formulation through successive modifications to presentation and integration, plan making in rural areas in India has evolved as a responsive democratic political process (Eckaus: n.d). Planning has been considering as an entwined part of development and is also argued to be an instrument to promote equitable development and inclusive growth. Das(2001) summarises that since the conditions of free flow of information and perfect mobility of resources for the proper functioning of market economy are rarely fulfilled, planning becomes important though not always an essential instrument for the overall development of economy(Das, 2001).

According to Rao (1989) in a country like India, the case for decentralised planning rests on four objectives. First, it is difficult for macro-level planning to effectively cover the resources of local significance and spatially-dispersed economic activities pursued on a small scale at the household and village levels. Second, bringing the peripheral groups of the poor and disadvantaged within the mainstream economic process requires programmes, personnel and organisational structures at the grass-root levels for identification, delivery, initial support and guidance towards viability. Third, given the likely slow pace of the rehabilitation of these groups and the frequent periods of stress through which they pass, stable and dependable arrangements are required for providing relief and supplying for basic needs. Fourth, it is important to have participatory mechanisms in the planning for resources and requirements, with a view to promoting among the people motivation, habits of selfhelp, local-level leadership and active role in strategic and planning decisions.

However, for the last few decades decentralised planning in India has witnessed vociferous criticism due to the long-existing issues of under development, growing regional disparities and the widening gap between the haves and have-nots. So the existing pattern of planning has provided a space for debate and discussion amongst the academics, scholars, policy maker and practitioner, which has also increased the importance of decentralised planning.

The current pace of development and flow of resources from the national to local governments also helps to enhance the visibility of the local governments in the implementation of developmental programmes, which further created a strong case to promote decentralised planning. Decentralisation through the involvement of local level representative institutions for the formulation of the plans for economic development as well as their implementation is being advocated in the interest of efficient utilisation of resources and for ensuring more equitable sharing of benefits from development (Mishra et al, 2000). It has also been argued by many scholars that decentralised planning requires a number of essential pre-conditions inter alia strengthening of the local governments with adequate devolution of resources and decision-making powers. 


\section{Local governments and decentralised planning in India}

The Local Self-Governing Institutions in India have attained prominence in formulating decentralised planning following enactment of the $73^{\text {rd }}$ Amendment Act in 1992 and the PESA Act in 1996. However, ever since independence, the endeavour to rejuvenate the LSGs started with an emphasis on people's participation in planning. According to Pal (2001), several attempts were made in the 1950s, 1960s and 1970s to operationalise district planning across the country. Although in some states model district plans were formulated, they could not be operationalised due to the non-existence of people's institutions.

However, weak local institution and non-existence of the local governments in some parts of India meant that decentralised planning could not become an inherent part of the national planning process. Contestation between the state and national governments over the institutionalisation of local governments' was also a major stumbling block for the formulation of the bottom-up plan, which not only invited the "bureaucracy-led sectoral planning" and "departmentalisation", but also adopted the centralised approach of planning in India. However, concentrated efforts to formulate decentralised planning in India were gradually cemented during different periods of time due to the recommendations of different commissions particularly after the recommendation of the Balawantarai G.Meheta Committee in $1957^{6}$.A number of commissions and study groups were also constituted (Table1) to review the functioning of the local governments and the institutionalisation of decentralised planning during the 1980s and all these commissions were suggested for the strengthening of the local governments to corroborate the district planning process.

During the 1970s, the Planning Commission also suggested the institutionalisation of State Planning Boards and the formulation of decentralised plans, but no sincere effort could ground such a process because of the absence of local governments in India (Alagh, n.d). However, despite the dismal functioning of the local governments, some states like Kerala and West Bengal took proactive measures towards the formulation of decentralised planning. The experience of Kerala to formulate decentralised planning is still considered as a model for the other Indian states.

\section{The $73^{\text {rd }}$ Amendment Act and decentralised planning in India}

The enactment of the $73^{\text {rd }}$ Constitutional Amendment Act (CAA) of 1992 was a landmark in the history of democratic decentralisation in India. The act provided ample scope to the local governments for developing and implementing local plans. Article $243 \mathrm{G}$ under this act visualises the

\footnotetext{
${ }^{6}$ Balawantarai G.Meheta Committee was formed in 1957 to examine the implementation of the community development programme and national extension service. The committee submitted its report in 1959, suggesting that "in the planning and execution of the C.D. programme while the states have got to lay down the broad objectives, the general pattern and measure of the financial, technical and supervisory assistance available, it is for the people's local representatives assisted by the development staff to work out and execute the details of the plan".
} 
role of the local governments for the preparation and implementation of plans for "economic development and social justice".

The Gram Sabhas have been vested with the powers to formulate plans, identify resources for implementation of such plans and select beneficiaries for the poverty alleviation and social security programs. Schedule Eleven of the $73^{\text {rd }}$ Constitutional Amendment Act listed twenty nine subjects by way of elaboration of Article $243 \mathrm{G}$ of the $73^{\text {rd }}$ Amendment Act which deals with the devolution of powers and responsibilities which may be entrusted to the Panchayats. Devolution of funds and functionaries has been given priority and provisions for the constitution of State Finance Commissions which were suggested as per the provisions of the $73^{\text {rd }}$ Amendment Act.

Further, Article 243ZD of the $74^{\text {th }}$ Amendment Act spelt out the Formulation of District Planning Committees (DPCs). Despite all these provisions, the local governments in India continue to suffer from inherent weaknesses, which dilute the fundamental objective of democratic decentralisation. Poor finances of the local governments, political interference in the decision-making process, presence of local elite in different decision-making bodies of the local governments and low level of awareness among the people and the elected members have diluted the essence of self-government, which has also blocked the road for decentralised planning.

\section{Scheduled Areas, decentralised planning \& PESA Act: understanding the link}

Planning for the Scheduled Areas was conceived as an important instrument for the national level planning process in India since the First Five-Year plan period. Scheduled Areas can be designated by the President, and although not defined in the Constitution, Scheduled Areas are usual defined as those with a preponderance of tribal population; compactness size and under-developed nature (Ministry of Tribal Affairs, 2015).The aim of decentralised planning in scheduled areas was to promote faster economic development in tribal areas and among the Scheduled Tribes (STs). Thus measures were taken by the central government (Govt. of India) to earmark special funds support for the Scheduled Tribes (STs). Concentrated efforts were also made by the central government and the various state governments to initiate an "integrated approach of development" which led to the Tribal Sub-Plan(TSP) strategy during the Fifth Five Year-Plan period in the country.

In the subsequent plan periods, planning for tribal development was given widespread importance and such initiatives paved the way for the emergence of multiple tribal development agencies such as the Integrated Tribal Development Agencies (ITDAs) and other cluster-development approaches such as the Modified Area Development Approach (MADA). However, planning for Scheduled Areas through a participatory democratic approach remained unattainable because of the strong presence of bureaucratic institutions like ITDAs and administrative departments (line departments) and emphasis on sectoral approach to planning. Particularly in the case of the TSPs, it was observed that these were 
often characterised by a "casual approach, lack of sincerity in implementation and absence of involvement of tribal people" (Menon, 2003) which has diluted the planning and implementation of the development programmes in these regions.

The enactment of the PESA Act in 1996 was a significant step towards promoting participatory planning in Scheduled Areas in India. The Act spelt out the role of PRIs in general and Gram Sabhas in particular for preparing Development Plans in the tribal areas, considering the magnitude of poverty, inequality and the nature and extent of underdevelopment in these areas, aiming to:

Promote the development of the Scheduled Tribes through respecting their culture, traditions and customs.

While vesting the Gram Sabhas and the Gram Panchayats with a greater role in the planning and implementation of development programs. The act has granted powers to the Gram Sabhas to approve of plans, programs and projects for social and economic development. The Gram Sabhas and Gram Panchayats were also given the responsibility of identification of beneficiaries under the poverty alleviation and other programs, providing certificates to the Gram Panchayats for utilisation of funds, ownership over natural resources-especially the minor forest produces and the power to control local plans and the resources for such plans including the Tribal Sub-Plans (TSP).

However, state-specific experiences show that scant attention has been given to the implementation of the PESA Act or the preparation of decentralised planning. The Eleventh Five-Year Plan (2007-12) however provided more attention to strengthening the decentralised planning process and in maintaining the spirit of the $73^{\text {rd }}$ Amendment and the PESA Acts in mind. The Ministry of Tribal Development, Government of India also issued guidelines ${ }^{7}$ to all the PESA states $\left(9\right.$ states $\left.^{8}\right)$ to provide priority to the Gram Sabhas and Gram Panchayats while preparing plans for economic development including the planning and implementation of programmes under the TSP. Realising the importance of decentralised planning in the context of the Eleventh Five-Year Plan, and the importance of the PESA Act, a committee was formed under V.Ramchandran (V.Ramchandran Committee ${ }^{9}$ ) which suggested the following points in order to formulate decentralised planning in the Scheduled:

- implementation of the PESA Act in different states is weak and the implementation should be taken up seriously.

- plans for TSP should be taken up in close coordination with the Gram Sabhas and PRIs.

- each state needs to constitute a group to look into the strengthening of the administrative machinery in the Scheduled V areas.

\footnotetext{
${ }^{7}$ Guidelines for planning and implementation of the TSP as per the provisions of the PESA Act. Ministry of Tribal Affairs, Government of India, May 2003.

${ }^{8}$ The nine PESA states are Odisha, Andhra Pradesh, Chhattisgarh, Jharkhand, Madhya Pradesh, Maharashtra, Rajasthan, Gujarat, and Himachal Pradesh.

${ }^{9}$ Report of the expert group on planning at the grass-root level-an action programme for the Eleventh Five Year Plan, March 2006, Ministry of Panchayati Raj, Government of India.
} 
- participation of vulnerable groups among the ST's like women in decision making bodies in PESA areas require more focus.

However, the commission could not provide detailed guidelines for the formulation of decentralised planning in the Scheduled Areas. The expert group perhaps tried to give a message that without proper implementation of the PESA Act, the planning process in these areas cannot be carried out in letter and spirit while adding the silver lining message that "the PESA Act should be implemented". However, despite the recommendations of the expert group and non-implementation or half implementation of the PESA act, decentralised planning was carried out in different states including Odisha. In Odisha, the process was initiated all over the state in 2008 under which the PESA districts were also covered.

\section{The present study, rationale and methodology}

The paper is a part of ongoing research work on "Decentralised Governance and Tribal Development in Scheduled Areas of Odisha" which aims to examine the process of the formulation of decentralised planning in the context of implementation of the PESA Act in the scheduled areas of Odisha (a state located in the eastern part of India). The main objective of the study also to examine the functioning of the local self-government in the scheduled areas in the state and how these institutions are playing a catalytic role in the matters of the formulation of the planning for the local development. The main source of the objective is based on the enactment of the PESA Act and functioning of decentralised self- governing institutions and promoting local development planning by these institutions in the tribal areas in the post-PESA enactment period. Based on this broad objective, the paper attempts to understand the process of decentralised plan in scheduled areas in Odisha, through a case of Sundargarh District.

The specific objectives of the study are;

- To understand the evolution of planning process and how the era of decentralised planning emerged the process of decentralisation and implemented through the local self-government in India.

- To unpack the functioning of the local self-governing institutions in the scheduled areas in Odisha in the context of enactment of the PESA Act in 1996 while highlighting their role in planning for economic development.

- To highlight the process of formulation of decentralised planning in scheduled areas while shedding light on the case of Sundargarh district of Odisha.

- To offer suitable policy recommendations for strengthening the process of decentralised planning in the scheduled areas under the framework of the PESA Act.

In the case of decentralised planning in Odisha, empirical studies have been carried out by researchers during different periods to understand the process of formulation of decentralised plans and role of LSGIs in preparation and integration of such plans. However, formulation of decentralised plans in 
the scheduled areas has not covered adequately. Therefore, the present paper tries to bridge this research gap, while analysing Sundargarh District, which is a tribal district (Scheduled District).

Sundargarh District is located in the northern part of the State which is surrounded by the State of Jharkhand and Chhatisgarh, and the Districts of Jharsuguda, Sambalpur, Angul and Keonjhar. Sundargarh is the second largest district of the state with a landmass of 9,712 sq.km $(6.24 \%$ of the state's territory) which spreads from the extreme north to the middle west in the state. The district has three administrative sub-divisions, eighteen Tahasils, seventeen CD Blocks and 262 Gram Panchayats. The district has 1,727revenue villages ${ }^{10}$ and 394,060 households. According to the 2011 census, the total population of the district is $2,080,664$ (4.96\% of state's population) out of which the percentage of urban population is $34.4 \%$.

The district was specifically selected for the study from a review of geographic locations and the profile of Scheduled Areas of the state. The district was also selected because of the high incidence of poverty, relatively weak local government and state of formulation of decentralised. Furthermore, familiarity of the researcher with the local language, culture and functioning of the local governance system were also other reasons for selecting the district as a unit of the study.

The data collection process was based on several rounds of exploratory field visits and extensive discussion with the different stakeholders, and the analysis of secondary data. For this purpose, a check-list was prepared based on the key objective of the study. The data collection process mostly involved the collection of quantitative data.

The data collection process was carried out in different phases. In the first phase, secondary data were collected to conceptualise the study and understand the research gaps. In this phase, literature was explored through using online search/web search and accessing different libraries. In this stage, data were collected from state library, state archives, and Panchayati Raj department, Govt. of Odisha, Bhubaneswar. The second round field visit was planned to collect the primary data from the PRI Members from two Panchayats in Sundargarh District through the process of focus group discussion and in depth interview. In this process we had also interacted with the traditional tribal leaders ${ }^{11}$, Govt. officials and villagers.

The data collection process was conducted through using qualitative tools and methods like focus group discussion and in depth interview. A comprehensive checklist was developed to gather the data through the process of FGD and in depth interview.

\footnotetext{
${ }^{10}$ Villages declared through the notification of the government. A revenue village is consist with few hamlets.

${ }^{11}$ Traditional tribal leaders are the head of their respective community or caste and usually decide the matters related to the socio-cultural and religious issues in a village. In the study area, each village has a traditional village council and the head of such council is known as the traditional leader.
} 


\section{Decentralised planning and local self-governing institutions in Odisha: an historical analysis}

Odisha since the pre-independence period is considered as one of the poorest states in India where $39.80 \%$ of the total population is below the poverty line (Planning Commission, GoI, 2004-05). The Odisha Human Development Report (OHDR), 2004 mentioned that the incidence of poverty in the northern and southern regions of rural Odisha accounts $75 \%$ of the state's total poor. The state has $22 \%$ of tribal population (2011 census) with 62 types of scheduled tribes (Ministry of Tribal Development, Govt. of India, 2014) who are primarily dependent on the various schemes and programmes implemented by the government departments and the Panchayats. The state has a vast tribal belt which is located in the southern and northern parts in the state mainly in the 13 districts out of which seven districts are fully and six districts are partly covered under the provisions of the PESA Act as well as the scheduled areas as referred to clause (1) of Article 244 of the Indian Constitution. However, the effects of these development programmes on the economic condition of the tribal people such as improving the physical and social quality of life is a matter of debate since these people are still languishing under the shadow of poverty and under development.

Table; 1: Administrative Profile of Odisha

\begin{tabular}{|c|c|c|c|c|c|c|}
\hline Landmass & \multicolumn{5}{|c|}{ Administrative Set-up } \\
\hline & Districts & Subdivisions & Tahasils & CD Blocks & Gram Panchayats & Villages \\
\hline $\begin{array}{c}155707 \mathrm{sq} \\
\mathrm{km}\end{array}$ & 30 & 58 & 316 & 314 & 6234 & 51349 \\
\hline
\end{tabular}

Source: Economic survey report, Odisha 2011-12

Odisha is one among the few states in India which enacted the Panchayati Raj system in 1948 through the Orissa Panchayati Raj Act of 1948. Even prior to this, the Panchayati Raj system existed in the state through different legal provisions. Since last 60 years, the Panchayats in Odisha have become sine qua non of the development of rural areas, addressing rural poverty while delivering equity and justice to the socio-economically backward people such as the Tribals. These institutions have emerged as the institution of self-government while promoting socio-economic and political transformation in the tribal areas through promoting participation in the local democracy and implementing a number of socio-economic development programmes. These programmes have become a major source of livelihoods for the tribal people. Further, these programmes have significant contributions towards addressing the development needs of the tribal people and the tribal area. The enactment of the PESA Act in 1997 in the state and extension of the provisions of this act to the tribal areas have also empowered the PRIs in these areas towards the formulating local development plan and promoting economic development and social justice. 
Decentralised planning in Odisha is closely linked with national level planning which falls under the aegis of the State Administrative Departments. The planning process in the state was confined to the political and bureaucratic circles, which restricted the participation of people and Local Governments until the Tenth Five-Year Plan. Thus, the process of formulation of decentralised planning evolved gradually as per the directives of the Central Government and the Planning Commission. The State Government in addition to following the directives of the Central Government, also tried to use its own "brain and pen" while framing appropriate policy mechanisms to make the plan decentralise and people centred.

In Odisha, a notable feature of the planning process was a "deliberate attempt to ignore the voices of the people from the marginalised and weaker sections, particularly the Scheduled Tribes (STs) while formulating plans for the economic development" (ibid) The State Pancahayti RajAct which was framed in 1948 and subsequently amended in 1964, 1968 and 1993, also provided space for Local Governments in the planning process. However, in the early days the planning process was managed by the State Planning and Coordination Department in which the LSGs played a negligible role.

Decentralisation of the planning process, which emerged as a key agenda of the National Government, also supported to the various state governments in India to redesign their planning mechanism. This process also helped to constitute the State Planning Board and subsequently devolved powers to the Local Governments in matters of planning. Gradually, the planning process evolved as a democratic process in the length and breadth of the state during different period particularly in the post- $73^{\text {rd }}$ Amendment period.

\section{Implications of decentralised planning in Scheduled Areas of Odisha}

Table 2 is a comparative presentation of the evolution of decentralised planning at the national level, in the state of Odisha and in the Scheduled Areas of the state.

Table-2: Evolution of Decentralised Planning Process in Odisha and its Implications in Scheduled Areas.

\begin{tabular}{|c|c|c|c|}
\hline \multirow[t]{2}{*}{ Period } & \multicolumn{2}{|l|}{ Evolution of Decentralised Planning } & \multirow[t]{2}{*}{ Implication in the Tribal Regions } \\
\hline & India & Odisha & \\
\hline $\begin{array}{l}\text { Early Phase } \\
(1951-1971)\end{array}$ & $\begin{array}{l}\text { From the First Five Year Plan to } \\
\text { the Fourth Five Year Plan the } \\
\text { nature of planning was centralised, } \\
\text { despite the suggestions given by } \\
\text { the Balawantarai.G.Meheta } \\
\text { Committee in } 1959 \text { for the } \\
\text { preparation of bottom up plan. In } \\
\text { 1969, the Planning Commission } \\
\text { issued guidelines to all the states } \\
\text { for the formulation of district plans. }\end{array}$ & $\begin{array}{l}\text { The planning process was } \\
\text { carried out on sectoral basis and } \\
\text { there was no effort to involve } \\
\text { people in the planning process. } \\
\text { The State Planning and } \\
\text { Coordination Department was } \\
\text { created to look into the plan } \\
\text { formulation process. }\end{array}$ & $\begin{array}{l}\text { The First and Second Five Year } \\
\text { Plans also emphasised on the } \\
\text { issues of under development of } \\
\text { the Scheduled Areas and } \\
\text { Scheduled Tribes. However, no } \\
\text { concrete efforts were made to } \\
\text { involve the local governments in } \\
\text { the planning process because of } \\
\text { the weak visibility of these } \\
\text { institutions and emphasis for } \\
\text { industrial as well as agricultural } \\
\text { growth during these periods. } \\
\text { Institutions such as Special } \\
\text { Multipurpose Tribal Blocks } \\
\text { (SMPTB) and Tribal Development } \\
\text { Blocks (TDB) emerged during this } \\
\text { period. }\end{array}$ \\
\hline
\end{tabular}




\begin{tabular}{|c|c|c|c|}
\hline $\begin{array}{l}\text { Evolution } \\
\text { Phase } \\
(1971-1992)\end{array}$ & $\begin{array}{l}\text { The Planning Commission } \\
\text { emphasised on the need for } \\
\text { bottom up planning and suggested } \\
\text { that all the state governments } \\
\text { should set up State Planning } \\
\text { Boards. The Ch. Hanumantha Rao } \\
\text { committee was formed to suggest } \\
\text { guidelines for decentralised } \\
\text { planning. Based on the } \\
\text { recommendations of this } \\
\text { committee's report' }{ }^{12} \text {, the Seventh } \\
\text { Five Year Plan focused on the } \\
\text { formulation of district decentralised } \\
\text { plans. For the first time, } \\
\text { decentralisation of the planning } \\
\text { process was given importance. } \\
\text { Decentralised Planning was also } \\
\text { recommended by the Ashok } \\
\text { Mehta Committee }{ }^{13} \text { in } 1978 \text { and } \\
\text { the GVK Rao Committee in } \\
1985^{14} \text {. }\end{array}$ & $\begin{array}{l}\text { During this period, the State } \\
\text { Government, as per the } \\
\text { guideline of the Planning } \\
\text { Commission established the } \\
\text { State Planning Board, and } \\
\text { keeping the mandate of the } \\
\text { TSP, sectoral planning process } \\
\text { was initiated in the tribal areas. } \\
\text { However, no concrete policy } \\
\text { mechanisms were devised to } \\
\text { involve the PRIs in the process } \\
\text { of decentralised planning. }\end{array}$ & $\begin{array}{l}\text { A special plan for tribal } \\
\text { development, in the name of Tribal } \\
\text { Sub-Plan (TSP) emerged during } \\
\text { this period with the objective to } \\
\text { steer up the development } \\
\text { initiatives in the tribal areas, by } \\
\text { provisioning special financial } \\
\text { grants. However, the emergence } \\
\text { of a number of rural development } \\
\text { programs emphasised on the } \\
\text { formulation of operational planning } \\
\text { at the block levels, which is } \\
\text { believed to be another reason for } \\
\text { the dilution of decentralised } \\
\text { planning. }\end{array}$ \\
\hline $\begin{array}{l}\text { Institutionali } \\
\text { sation } \\
\text { Phase } \\
(1992-2007)\end{array}$ & $\begin{array}{l}\text { The enactment of the } 73^{\text {rd }} \\
\text { Constitution Amendment Act and } \\
\text { the PESA Act further specified } \\
\text { explicitly the essence of } \\
\text { decentralised planning. The role } \\
\text { of the PRls in district planning got } \\
\text { paramount importance. The } \\
\text { Ministry of Panchayati Raj was } \\
\text { formed at the Centre in } 2004 \text { to } \\
\text { fulfill the mandate of the } 73^{\text {rd }} \text { CAA. } \\
\text { V.Ramchandran Committee } \\
\text { submitted its report while } \\
\text { encompassing the formulation of } \\
\text { meaningful plans within a detailed } \\
\text { time schedule. However, no } \\
\text { guidelines were provided for the } \\
\text { Scheduled Areas. }\end{array}$ & $\begin{array}{l}\text { Keeping the mandate of the } 73^{\text {rd }} \\
\text { Amendment Act, the State } \\
\text { Government amended the } \\
\text { state's Panchayati Raj Acts and } \\
\text { emphasised the need for } \\
\text { decentralised planning. The } \\
\text { Odisha District Planning } \\
\text { Committee Act came into } \\
\text { existence in } 1998^{15} \text { and Rule in } \\
2000^{16} \text { which ensured the } \\
\text { formation of the DPCs. } \\
\text { Implementation of the PESA Act } \\
\text { also further emphasised the } \\
\text { essence of the local } \\
\text { governments in formulating } \\
\text { decentralised plans in tribal } \\
\text { areas. }\end{array}$ & $\begin{array}{l}\text { District Planning Committees were } \\
\text { constituted in all the districts after } \\
\text { the } 2002 \text { Panchayat elections. The } \\
\text { provisions of the PESA Act also } \\
\text { further suggested the role of the } \\
\text { people and the PRIs in planning } \\
\text { for the Scheduled Areas. However } \\
\text { planning for the implementation of } \\
\text { the TSP could not take place as } \\
\text { per the provisions of the PESA } \\
\text { Act. Further, recommendations of } \\
\text { the V.Ramchandran Committee } \\
\text { were also not taken into } \\
\text { consideration while developing } \\
\text { plans in Scheduled Areas. }\end{array}$ \\
\hline $\begin{array}{l}\text { Devolution } \\
\text { Phase } \\
\text { (2007 } \\
\text { onwards) }\end{array}$ & $\begin{array}{l}\text { The Central Government and the } \\
\text { Planning Commission emphasised } \\
\text { on the preparation of the district } \\
\text { plans and the activation of the } \\
\text { DPCs. The Ministry of Tribal } \\
\text { Development at the centre and the } \\
\text { Planning Commission also } \\
\text { suggested that the PESA states } \\
\text { should prepare plans under TSP } \\
\text { by involving the PRIs. The } \\
\text { Planning Commission also } \\
\text { developed and issued a manual } \\
\text { called the Manual for Integrated } \\
\text { District Planning (MIDP) to the } \\
\text { states. }\end{array}$ & $\begin{array}{l}\text { In the case of Odisha, the State } \\
\text { Government laid more emphasis } \\
\text { on the formulation of district } \\
\text { plans in the context of the } \\
\text { Eleventh Five year Plan (2007- } \\
\text { 12). The District Planning and } \\
\text { Monitoring Unit (DPMU) was } \\
\text { constituted in all the districts. } \\
\text { Planning through the PRIs was } \\
\text { adopted as a policy of the State } \\
\text { Government. }\end{array}$ & $\begin{array}{l}\text { Decentralised planning process } \\
\text { was initiated in all the districts. } \\
\text { However, the process could not } \\
\text { provide any specific focus on } \\
\text { formulating plans in the tribal } \\
\text { districts/areas. No initiative was } \\
\text { taken to follow the basic premise } \\
\text { of the PESA Act while developing } \\
\text { plans in the Scheduled Areas. }\end{array}$ \\
\hline
\end{tabular}

Source: Analysis of secondary data and reports of the various commissions on decentralisation.

\footnotetext{
${ }^{12}$ Report of the Working Group on District Planning (Ch. Hanumantha Rao Committee Report) Part-I and Part-II, New Delhi, Planning Commission.

${ }^{13}$ Ashok Mehta Committee submitted its report in 1978 while examining the pattern of Local-Self Governments in India. The committee, in its report, noted that "with the district as the strategic level for planning, the Zilla Parishad should be made responsible for planning at the district level. Intensive exploitation of new opportunities of resources earmarked for the weaker sections should be a plan process itself". In the context of weaker sections, particularly to the Scheduled Tribes, the commission suggested adequate seat reservation by mentioning that “...their representation in all Panchayati Raj Institutions should be on the basis of their population".

${ }^{14}$ A Committee under GVK Rao on "Administrative Arrangements for Rural Development and Poverty Alleviation Programmes" was formed in 1985 and the committee suggested that "the Zilla Parishad should be the apex body for the overall planning at the district level. It should be assisted by a District Planning Board (DPB), which should be an advisory expert body with a planning cell".

15 The Odisha District Planning Committee Act 1998, Orissa Act 8 of 1998, Law Department, Government of Odisha, the $8^{\text {th }}$ of October, 1998.

16 The Odisha District Planning Committee Rule, 2000, Planning and Coordination Department, the 11 ${ }^{\text {th }}$ of December, 2000.
} 


\section{Decentralised planning in Odisha: the present scenario.}

Odisha as discussed earlier has witnessed extensive formulation of decentralised district plans since the year 2008 in which the Panchayati Raj Institutions (PRIs) and other stakeholders including the people have played a key role. The process of the formulation the plans started in 2008 and under this process all the 30 districts of the state were covered. In consultation with Government of India in Ministry of Panchayati Raj and Planning Commission, Government of Odisha initiated for the formulation of district plans for all 30 districts. The process was carried out in a consultative and participatory manner in which the Gram Sabhas and Gram Panchayats in rural areas and Urban Local Bodies (ULBs) ${ }^{17}$ in the urban areas played a significant role.

The following are the major achievements of the planning process, based on analysis of state level secondary data:

Regular process: The formulation of the Annual and Five-Year Perspective Plans as well as plans for the different Central Sponsored Schemes (CSS), including the Mahatma Gandhi National Rural Employment Guarantee Scheme (MGNREGS), Backward Region Grant Fund (BRGF), Rashtriya Krishi Vikash Yojana (RKVY) and National Rural Health Mission (NRHM), have become a regular affair in the state. As a result, the District Plans are being prepared and vetted each year at the DPC level before submitting to the State Government for integration and financial approval.

Institutionalisation of the Panchayats (PRIs): The State Government has taken proactive measures to strengthen the institutions of local governments over the period of time. State specific acts have been amended keeping in view the $73^{\text {rd }}$ Amendment Act and the provisions of the PESA Act. Regular elections of the rural local governments (1992, 1997, 2002, 2007 and 2012) and the functional and financial devolutions have been taken up proactively.

Devolution of funds and functionaries: The state government has devolved the functions of Twenty One Subjects of Eleven Departments ${ }^{18}$ to the PRIs in order to strengthen their functioning and the district planning process. Allocation of funds to the PRIs under the State Plan Funds has been increased over the period of time. Funds under MGNREGS, Indira AwasYojana ${ }^{19}$ (IAY), Old Age Pension (OAP), Finance Commission Grants (national level), State Finance Commission Grants (devolution funds), etc., have been enhanced and provided to the local governments, which is considered as a positive trend in the process of devolution.

\footnotetext{
${ }^{17}$ In Odisha, the Urban Local Bodies(ULBs) created as per the provision of the $74^{\text {th }}$ constitutional amendment act and basically they are divided into three categories i.e. Municipal Corporation(for Mega Cities), Municipalities(for Medium cities/towns) and Notified Area Councils(NACs) (for small towns)

${ }^{18}$ Twenty one subjects of 11 departments namely Agriculture, Cooperation, School and Mass Education, Food Supplies and Consumer Welfare, SC and ST Development, Health and Family Welfare, Women and Child Development, Fisheries and Animal Resources Development, Rural Development, Panchayati Raj and Water Resources have been transferred to the PRIs.

${ }^{19}$ A housing scheme of the Govt. of India for the rural poor and it is implemented through the local government in Odisha.
} 
District sector schemes and allocation of funds: District sector schemes are included under a separate budget head. Special funds have been earmarked for the targeted districts to accelerate the development process for the eradication of poverty. Table-2 provides the status of the allocation of funds to districts under the decentralised planning during the financial year 2009-2010to 2012-2013.

Table2; Proposed Outlay to Districts under District Sector Plan

\begin{tabular}{|c|c|c|c|}
\hline Year & $\begin{array}{c}\text { State Plan } \\
\text { (Rs. crore) }\end{array}$ & $\begin{array}{c}\text { District Plan } \\
\text { (Rs. crore) }\end{array}$ & $\begin{array}{c}\text { Outlay for Targeted Districts } \\
\text { (Rs. crore) }\end{array}$ \\
\hline $2009-2010$ & 7214 crore & 3434 crore & N.A \\
\hline $2010-2011$ & 10010 crore & 5556 crore & N.A \\
\hline $2011-2012$ & 12005 crore & 7092 crore & 1193.45 crore \\
\hline $2012-2013$ & 17200 crore & $9095.83 c r o r e$ & . \\
\hline
\end{tabular}

Source: (i)Planning and Coordination Department, GoO, (ii) Ministry of finance, Government of Odisha. Note: Datagiven in 2012-2013 years is proposed outlay, based on the $12^{\text {th }}$ five year plan of the state. Note: 1 Crore $=10$ million; $1,000 I N R=15.6$ USD

Table 2 shows that $53 \%$ of the total State Plan Fund, i.e. Rs. 9095.83 Crores during the financial year 2012-2013 has been earmarked, under which the districts will have to prepare plans and implement different development programs accordingly. Special attention has also been given to the tribal and backward districts by provisioning special funds.

Emphasis on implementation of the PESA Act: The State Government has also taken several steps for strengthening the implementation of the PESA Act in the state, which is believed to have provided an advantage to district planning. Powers have been vested with the Gram Sabhas and Gram Panchayats for the preparation of plans, management of natural resources, and implementation of development programs. Further, state subject laws pertaining to forests, mines, and excise also have been amended.

Formation of District Planning Committees: District Planning Committees (DPCs) have been constituted in all the districts in accordance with the mandates of the Odisha District Planning Committee Act, 1998, and the Odisha District Planning Committee Rule, 2000. Further, capacity building of the DPC members and funds allocation to the DPCs to function as an institution has been taken up and District Planning and Monitoring Units (DPMUs) have also been formed in all the districts to work as support agencies for the DPCs.

\section{Decentralised planning in the scheduled areas: the case of Sundargarh District}

The process of the formulation of decentralised district plan in Sundargarh district was carried out by the district administration during the year 2008. The process was carried out as per the guideline of Planning Commission (Government of India) and the Planning and coordination department, Govt.of Odisha. Furthermore, for the smooth facilitation of the process, the Govt. of Odisha had appointed a 
technical support institution (TSI) for each district. The entire process was continued for six months with involving various stakeholders including the Panchayati Raj Institutions.

Since the district is predominately a tribal district with a vast geographical area $\left(2^{\text {nd }}\right.$ large District in Odisha) where the tribal population is more than 50\%(2011 census report) of the total population and has been declared as a schedule District (as per the provision of PESA Act, 1996), for the first time an initiative was taken up for the formulation of a comprehensive District plan. Prior to this, several attempts were taken for the formulation sectoral plans for the District. (National Food for work plan in 2005, Micro-plan by forest department and Perspective Agricultural plan of District Agriculture department). So for the first time a scope was created for the Panchatari Raj institutions of the District to develop a comprehensive District plan, where the Gram Panchayats had taken a lead role.

\section{The process of plan formulation}

District Vision Document: The District Vision Document for the year 2020 has been prepared and revisited each year prior to the formulation of the annual plan. The document is prepared through a consultative process by organising a series of meetings with the different stakeholders. In the case of Sundargarh, five major sectors have attained priority in the District Vision Document: rural connectivity; education; infrastructure development; women's and children's development, and water and sanitation (District Planning Office, Sundargarh, 2012).

The vision document was the main source of preparing a comprehensive district development plan. The district vision document of 2020 was prepared through a series of consultations. These consultations were held at the different important locations of the district such as district head quarter, block head quarter, pamchayat head quarter and at the head quarters of the ULBs. These meetings were arranged to a vision document for the respective area while envisioning on various development issues. Further the emerged issues were compiled for the preparation of a district vision document. The issues were identified in keeping the year 2020 in mind and based on this, the annual plan and five year plan were prepared for the district.

District resource envelope: The District Resource Envelope $\mathrm{e}^{20}$ has been prepared by calculating the available resources in the district. While doing so, an attempt was also made to incorporate the existing natural and human resources. The District Sector Schemes were given priority while preparing the District Resource Envelope. For the year 2012-2013, the size of the District Resource Envelope has been estimated to be Rs. 1235.37 crores as against the available of Rs.1133.66 crores, leaving a resource gap of Rs.1017.1 crores which is $8.23 \%$ of the required amount.

\footnotetext{
${ }^{20}$ The District Resource Envelope is a calculation of the total resources of a district-Financial, Human and Natural Resources. It helps to understand the actual need and available resources and helps to plan for either surplus or deficit resources.
} 
Box-1, Major Components of the District Resource Envelope

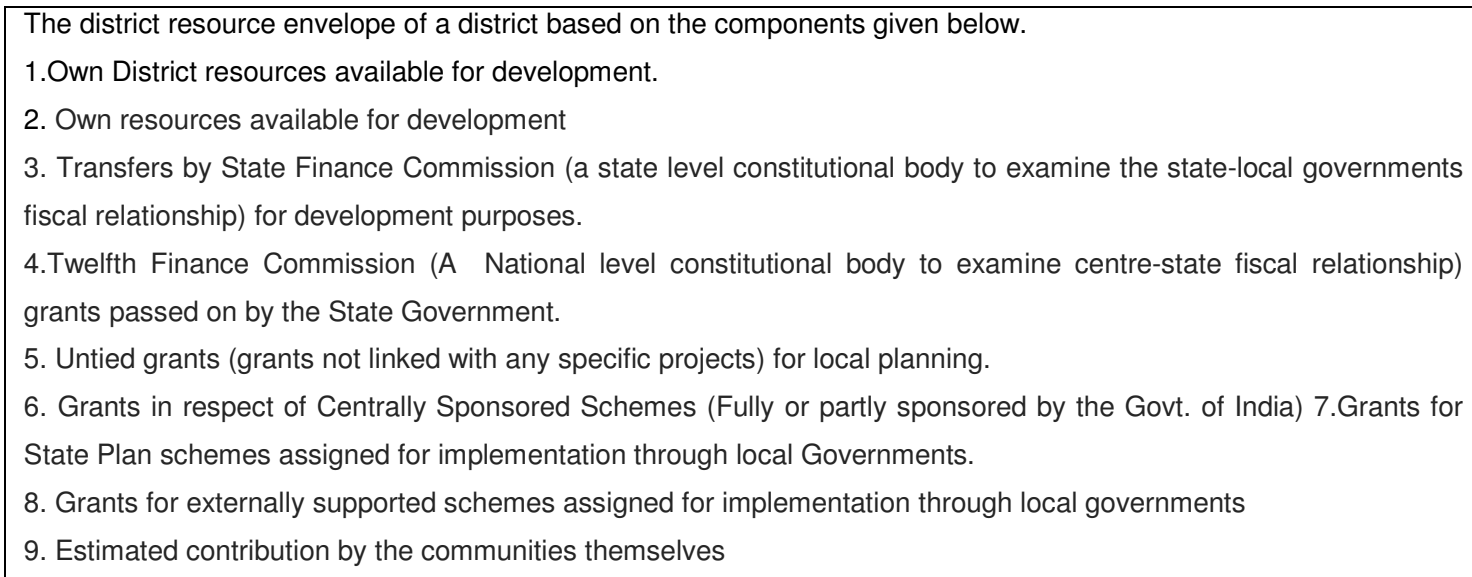

Source: Guideline for formulation of District Plan, Planning and Coordination Department, Odisha, Bhubaneswar, 2012-13.

Annual and Five-Year Perspective Plans: Annual and Five-Year Perspective Plans have been formulated by the panchayats with the support of the District Planning and Monitoring Unit (DPMU) keeping in view the Eleventh and Twelfth Five-Year Plans. An annual estimation of Rs. 1235.37 crores (DPO, Sundargarh: 2012) for the year 2012-2013 has been calculated as the resource requirement for the district to implement different schemes and programs. The Five Year Perspective Plans for 2008-2012 and 2012-2017 have also been prepared and endorsed by the District Planning Committee.

Constitution of the District Planning Committee: The District Planning Committee has been functional since the year 2002 and currently there are 20 members-including 11 from Zilla Parishad (ZP), five from Urban Local Bodies (ULBs), and four nominated members. The average sitting of the DPC is twice a year as per the data available in the District Planning Office.

Planning under Tribal Sub-Plan and Role of PRIs: The local governments in the District have shown unprecedented enthusiasm towards the process of the formulation of decentralised plan. Planning for the TSP was carried out along with the other sectoral plans. Under each sector, special funds were earmarked for the Tribal-Sub Plan, considering the preponderance of the tribal population and the nature of underdevelopment of these groups.

\section{Major findings}

Less emphasis on Tribal development: The entire process created a vacuum in the case of Planning for Tribal Development as per the provisions of the PESA Act. From the field observation, discussion with the various government officials and Panchayat members and analysis of secondary data, particularly the district annual plan documents, resolutions of the meetings of the Gram Sabhas, Gram Panchayats and the District Planning Committee, it is revealed that scant attention was paid towards the integration of aspects of tribal culture, customs and traditions in planning. Even in the case of formulation of plan under the Tribal Sub-Plan, as part of the planning process no emphasis was given 
to follow the provisions of the PESA Act in letter and spirit. The Gram Sabhameeting resolutions collected from the two Gram Panchayats showed that the Gram Sabhas only discussed such projects and programmes as the MGNREGS and IAY, for which funds were earmarked, while plans for holistic development seemed to be missing. Furthermore, planning for the implementation of the TSP did not receive special focus because of the absence of a well-devised mechanism and the persisting gap between the PRIs and the tribal development agencies.

Planning and implementation - the issue of funds: The whole planning process, starting from the formulation of the Vision Document to the finalisation of the District Plan is dominated by the issue of funds. The increasing gap between the proposed outlays and the actual allocation raised several questions about the usefulness of this process. Table 3 presents the projected gap between available and required funds under three major sectors for the year 2012-2013.

Table3: Sector-wise analysis of resource requirement and resource availability of three major sectors during 2012-2013 Year (Rs.in lakhs).

\begin{tabular}{|c|l|c|c|c|}
\hline Year & \multicolumn{1}{|c|}{ Sector } & Resource Requirement & $\begin{array}{c}\text { Resource } \\
\text { Availability }\end{array}$ & Resource Gap \\
\hline \multirow{2}{*}{ 2012-2013 } & Social Service & 48799 & 46174 & 2625 \\
\cline { 2 - 5 } & Rural Development & 10219 & 7798 & 2421 \\
\cline { 2 - 5 } & $\begin{array}{l}\text { Agriculture and } \\
\text { allied sector }\end{array}$ & 9049 & 5934 & 3115 \\
\hline \multicolumn{2}{|l}{ Total } & $\mathbf{6 8 0 6 7}$ & $\mathbf{5 9 9 0 6}$ & $\mathbf{8 1 6 1}$ \\
\hline
\end{tabular}

Source: District Planning and Monitoring Unit (DPMU), District Planning Office, Sundargarh Note: 1 lakh $=100,000$

Table 3 shows that the required resource for three major sectors is calculated as Rs.68067 lakhs while resource availability is Rs.59906 lakhs. Thus, the estimated gap is Rs.8161 lakhs which is $11.98 \%$ less than the requirement. However, there is no concrete plan for adjusting the gap, which was another important aspect of the planning process.

Integration: Issues of integration between the different sectoral plans were clearly lacking, which emerged as a biggest challenge in the whole process. In the case of scrotal plans, such as the TSP, Sarva Sikshya Abhiyan (SSA), and the National Rural Health Mission (NRHM), the integration was clearly absent.

Departmental plan vs.district plan: In the case of Sundargarh District, it was observed that some departments had separate plans as per the guidelines of their respective department/ministry, which was another way to dilute the district planning process. Even under the flagship programmes such as the SSA, NRHM, Rashtriya Krishi Vikash Yojana (RKVY), the respective departments had their own plans in which the recommendations of the Gram Sabhas and the Gram Panchayats were not taken into consideration. 


\section{The PESA Act and institutionalisation of the PRIs}

Since the two decades of enactment of the $73^{\text {rd }}$ Constitution Amendment Act (CAA) and 15 years after the enactment of the PESA Act, no sincere efforts have been made to augment the capacity of the PRIs in the district. Weak institutional arrangements, ambiguity in functional role, coordination gap among the different tiers, and above all, unfinished devolution agenda of the State Government abated the functions of the PRIs not only in the district but also other tribal districts. While on one hand there is strong resistance from the bureaucracy to work under local government institutions, on the other hand, there is the sheer negligence of the State Government to implement the PESA Act, which has created confusion among the PRIs and ultimately hampered the planning process.

District resource envelope: unrealistic and unscientific calculation of resources: There has been no emphasis on the mapping of locally-available resources such as community forests, grazing lands, minor minerals and their inclusion in planning. Poor data (cultural, resource, and statistical data) has also been a disabling factor, and in the case of the district it was observed that no sincere efforts have been initiated by the PRIs to that regard. Even in the case of availability of such data, no measures were taken to integrate the value of such resources while preparing the District Resource Envelope.

Macro-perceptions and micro-expectations: The process witnessed a huge contestation between the macro-level perceptions and the micro-level expectations with regard to the planning for development programmes of the district. In the case of rural connectivity, $60 \%$ weighting was given to this sector by the people, but the allocated amount to the sector was only $40 \%$ under the BRGF during the year 2011-2012. There is therefore a huge gap between the perceptions of the people of rural and urban areas, tribals and non-tribals, line departments and the PRIs were also other significant aspects of this process.

Gram Sabha - a weak institution: Under the PESA Act, special powers have been given to the Gram Sabhas as far as the planning and implementation of the development programs is concerned. However, the process of district planning reveals that the Gram Sabhas in the district could not articulatepeople's aspirations effectively in a larger forum. The huge gap in the capacity of the PRI members, political interference in decision-making processes and the dominance of the local elites in matters of planning diluted the importance of the Gram Sabhas and turned them into just another wing of bureaucracy.

Less emphasis on customs, traditions and culture of the Scheduled Tribes: From the field study, data collection and interaction with the key stakeholders such as Panchayat members, Village Elders, Tribal leaders, it evident that the planning process was carried out without adequately assessing the customs, traditions and cultural practices of the tribal people in the district. Being a Scheduled 
District, and despite the strong presence of the traditional pattern of governance, no plan was developed to converge these two patterns, during the process.

Less focus on resource-generation plans: Despite the rich natural resources including forests, water bodies, and mines in the district, no plan was made by the PRIs to map them for economic purposes. The district resource generation plan was based on the financial grants received from the National and State Governments under the different schemes and programmes without judiciously calculating the available natural resources.

Presence of elites: The presence of the local political leaders and socio-economically advanced persons in the Gram Sabhas and their dominance in the planning process hindered the participation of the people particularly those from the Scheduled Tribes. People from the upper castes dominated the whole process despite the strong presence of the Scheduled Tribes in the district. While discussing with the villagers (community members) and tribal leaders, many of them described how politically powerful and economically rich people have dominated the process of conducting Gram Sabhas and village meetings for the formulation of plans.

Bureaucratic control: The District planning process, starting from Palli Sabhas ${ }^{21}$ and Gram Sabhas to the district was more or less controlled by the district level officials such as the Block Development Officers (BDOs) and DRDA officials. This restricted the role of democratic institutions such as the Gram Sabhas and the Gram Panchayats and undermined their constitutional legitimacy.

Dismal functioning of the DPC: The functioning of the District Planning Committee (DPC), which was constituted in 2002 in the district under the Odisha District Planning Committee Rule, 2000, has been more or less confined within a certain boundaries. Despite being a tribal district, the tribal development issues were not discussed seriously in the DPC meeting. The huge capacity gap and political interference has restricted the functioning of the DPC in the district.

Lack of emphasis on intra-district tribal development issues: The process of district planning did not appropriately consider the intra-developmental variances despite the guidelines of the Planning Commission and the State Planning and Coordination Department. Even in the case of the area development Programmes like the BRGF, the planning process did not consider the nature and extent of the region-specific under-development issues. Being a district affected by Left Wing Extremism (LWE), no sincere effort has been made to give due emphasis to such areas while planning, budgeting, and allocating funds.

\footnotetext{
${ }^{21}$ Palli Sabha is the village level institution in Odisha as per the structure of the panchayati raj system. It is the village level body responsible for planning and programme implementation.
} 


\section{Recommendations}

A number of recommendations come out of the study:

- Implementation of the PESA Act should be taken up in letter and spirit. In this context, there is a need to relook into the current status of implementation and have a clear cut timeline to actualise this act.

- Specific guidelines should be developed to formulate decentralised planning in the Scheduled Areas. The guidelines should be based on the traditions, customs, and the cultural identity of the tribal people.

- Issues related to the devolution of funds, functions, and functionaries need further review and the PRIs in the Scheduled Areas should be given more priority while doing this. Special cadres for the Panchayats should be developed and they must provide adequate training.

- Instead of devolving more funds to the district administrations, funds should be channelised through the PRIs, and in this connection funds under the Tribal Sub-Plan(TSP) must be channelised through the Zilla Parishad and the functioning of ITDAs should be brought under the control of the Zilla Parishad. The Gram Panchayats should be given priority in the planning and implementation of the programmes of the TSP.

- The local governments should possess updated information about tapping the existing sources to promote the development programs. The resource-mapping exercise should be made mandatory for all the tiers of the local-governments.

- The tribal areas are rich in natural resources which can be exploited for the implementation of development programs. The PRIs should take control over such resources and this should be reflected in the planning process.

- The planning exercise carried out by the different departments for schemes and programs such as the SSA, NRHM and RKVY should not be made in parallel. Involvement of the PRIs at the respective level must be ensured in keeping the mandate of the PESA Act in mind.

- Planning of ITDAs and other tribal development agencies should be in close coordination with the PRIs at their respective level. There should be no parallel planning exercise.

- Coordination among the different tiers should be taken up seriously by reviewing the current institutional arrangement pattern and fund flow to different tiers. Convergence plan should be followed up in letter and spirit. 
- Functioning of the DPCs in the districts in general and Scheduled Areas in particular must be reviewed from time to time in order to enhance their efficacy. Development issues should be given priority while conducting the DPC meetings. Achievements of the district planning process, principles of fund allocation to the districts, and implementation of the development programmes should be discussed in the DPC meetings.

- The PRIs in the Scheduled Areas must take ownership of the planning process and involve in the process wholeheartedly. Participation of the people in Gram Sabhas must be encouraged and the best-performing Gram Sabhas and Gram Panchayats should be further motivated.

\section{Conclusion}

Decentralised planning has a noble objective which can be achieved through a systematic strategy. The major focus should be based on integrating people's participation with the democratically decentralised local governments. However, the case of Sundargarh District in Odisha has revealed the sluggish progress of decentralised planning after the implementation of the PESA Act, 1996. The process so far seems to be in a nascent stage in the Scheduled Areas of Odisha, and this needs to be addressed through specific attention from the policy makers and planners. The process should be taken up rigorously by devising the appropriate policies. The local governments should be augmented with appropriate powers and functions so that they can take the process forward.

A local resource mapping exercise should be made a part of decentralised planning, and it should be in the tune with the customs, traditions, and the cultural identity of the tribal people. If careful attention is paid to prepare need-based and area-specific plans in the Scheduled Areas, sustainable development through people's participation can be achieved which would ultimately contribute towards the strengthening of democratic governance in the tribal regions of the state.

\section{References}

Alagh, YK(n.d),Panchayati Raj and Planning in India: Participatory Institutions and Rural Roads, Asian Institute of Transport Development, New Delhi.

Das, PS (2001).Decentralized Planning and Participatory Rural Development, Concept Publishing, New Delhi.

District Planning Office, Sundargarh (2012); District Planning and Monitoring Unit,

Sundargarh.www.sundargarh.nic.in

Eckaus, RS, (n.d); Planning in India, Massachusetts Institute of Technology; PP 306-307.

Gopabandhu Academy of Administration, (2003): Decentralised Planning, A Training Module (DLM), Bhubaneswar.

Government of Odisha (2012), Ministry of Planning and Coordination, Government of Odisha, 2012.www.Govodisha.nic.in

Government of Odisha (2012), Ministry of Panchayatiraj, Government of Odisha, 2012, www.Govodisha.nic.in

Gulati, I.S, (1986): Decentralised Planning: Loopholes that Remain, Economic \& Political Weekly, August 9$15,1986$. 
Menon, PSK, (2003): Report on Impact of the Tribal Sub-Plan Implementation in Improving the SocioEconomic Condition of the Tribal People with Special Focus on Reduction of Poverty Level Covering the States of Assam and Tamil Nadu, Institute of Social Sciences, New Delhi, PP 38-39.

Ministry of Tribal Affairs (2015) Definition of Scheduled Areas http://tribal.nic.in/Content/DefinitionofScheduledAreasProfiles.aspx

Mishra SN, Mishra S \& Pal C, (2000): Decentralised Planning and Panchayati Raj, Mittal Publications, New Delhi.

Planning Commission(2006), Report of the Working Group on Democratic Decentralisation and PRIs, November, 2006.

Pal,M (2001): Decentralised Planning and Panchayati Raj, Report of Working Group in Tamail Nadu, Economic \& Political Weekly, March 24-30, PP 1002.

Rao, V.M (1989): Decentralised Planning, Priority Economic Issues, Economic \& Political Weekly, June 24-30, PP1399-1400

Upadhaya, S, (2004): Tribal Self-Rule Law and Common Property Resources in Scheduled Areas of India-A New Paradigm Shift or Another Ineffective Sop? Seminar Paper presented at $10^{\text {th }}$ Biennial Conference of IASCPR, August 2004, Mexico. 